\title{
Murder, mortsafes and Moir: a medical student looks at anatomy teaching in Aberdeen
}

\author{
E Humphries \\ $5^{\text {th }}$ year medical student, University of Aberdeen, Scotland
}

\begin{abstract}
During the eighteenth and early nineteenth centuries anatomy theatres in Scotland suffered from a shortage of cadaveric material. Medical students and their teachers were eager to improve their medical education and began to look for ways to further their anatomy knowledge and so turned to bodysnatching. Bodysnatching failed to meet the demand so some resorted to murder to acquire cadavers, sometimes in exchange for money. Bodysnatching became common throughout the British Isles and prompted the 1832 Anatomy Act, which allowed unclaimed bodies to be used for dissection.
\end{abstract}

KEYWORDS Bodysnatching, Aberdeen, Andrew Moir, Aberdeen Medical Society

Correspondence to E Humphries II 3 Caiyside Edinburgh EHIO 7HR Scotland

tel 0759002364 I

e-mail

Emma.humphries.09@aberdeen.ac.uk

DECLARATIONS OF INTERESTS No conflicts of interest declared.

\section{INTRODUCTION}

Bodysnatching was a common practice in Britain in the eighteenth and early nineteenth centuries. Bodies that had been recently buried were dug up or victims were killed and their cadavers were used by lecturers to teach anatomy. Arguably the most famous bodysnatchers were William Burke and William Hare, who killed 16 people in Edinburgh between November 1827 and October 1828 and then sold the corpses to Dr Robert Knox, a private anatomy lecturer.' While Edinburgh is perhaps the best known setting for these gruesome events, other parts of Scotland also have their own dark history. Aberdeen is no exception and this paper reviews the teaching of anatomy in Aberdeen around the time of Burke and Hare, the techniques of bodysnatching as well as the deterrents employed.

\section{ANATOMY TEACHING IN ABERDEEN}

The University of Aberdeen was founded in 1495 and from the earliest years had a 'mediciner' as a principal teacher. ${ }^{2}$ The 'mediciner' was one of the four original academic doctors, with some knowledge of human anatomy and of certain medical treatments and trained to administer medication. The university was the first on record in the British Isles to have a chair of medicine. Professors of medicine were appointed in Cambridge and Oxford in 1540 and 1546 respectively. Dublin then followed with a chair of medicine in 1618, Glasgow in 1637, Edinburgh in 1685 and St Andrews in 1721 . William Gordon, a professor in medicine at Kings College, Aberdeen, was granted permission by the Privy Council to teach human anatomy at the University of Aberdeen in 1636. He had taught general anatomy through the dissection of animals for two years prior but wanted to teach human anatomy. He asked the municipal authorities to provide him with bodies so that they could be 'publiclie anatomized'. The Privy Council directed the sheriffs, provost and baillies of Aberdeen and nearby Banff to supply two bodies of executed 'malefactors', or failing that, bodies of the poor who had 'few friends or acquaintances'.

Despite the minimal anatomy teaching in Aberdeen at the time, students were eager to persevere and to further their knowledge in the subject. ${ }^{3}$ Lectures focused on the teachings of Aristotle and Galen, both of whom had carried out anatomical dissection of live and dead animals, such as pigs and primates; students would dissect a dog and a calf's head each week and occasionally a fetus or a stillborn baby would be obtained. ${ }^{3}$ If these were not available, bodies were sometimes purchased from London for the sum of 20 pounds. ${ }^{3}$ Students then used these bodies to study osteology, examine blood vessels and learn about blood circulation, the brain, nerves, viscera, the thorax and the abdomen.

\section{BODYSNATCHING IN THE NINETEENTH CENTURY}

Although most medical schools in the UK were being provided with some cadaveric material, dead bodies were in high demand among medical students and doctors. Instead of waiting for their annual supply of bodies (as allowed by the Privy Council), students, often encouraged by their teachers, started to steal bodies. The practice was of course illegal and began with the unscrupulous digging up of newly buried bodies from graveyards for sale to those who wanted them. This lucrative practice was taken up by criminals, some of 
whom eventually resorted to murdering members of the public when the supply of dead bodies dried up. The bodysnatchers were divided into two groups: the amateurs and the professionals. The amateurs were medical students and lecturers who wanted the bodies to dissect themselves. ${ }^{4}$ The professional bodysnatchers were felons who were only concerned with receiving money for the corpses, such as the famous Burke and Hare in Edinburgh. There were many different names for the people who undertook this gruesome practice at the time: ${ }^{4}$ bodysnatchers, grave robbers, sack-em-up men, shusy-lifters, corp'-lifters, Burkers, noddies, and resurrectionists (the name by which they were known in Aberdeen) (Figure I).

When some of these felons graduated to murder, many people in Scottish cities would not go anywhere near the medical schools at night in case they were kidnapped or snatched with an iron 'cleik' (a large hook) and killed by medical students in this way. ${ }^{3,4} \mathrm{~A}$ 'pitch-plaster' was the most common technique used by 'Burkers'; a large plaster coated with soft tar was used to quickly suffocate the victim. ${ }^{5}$

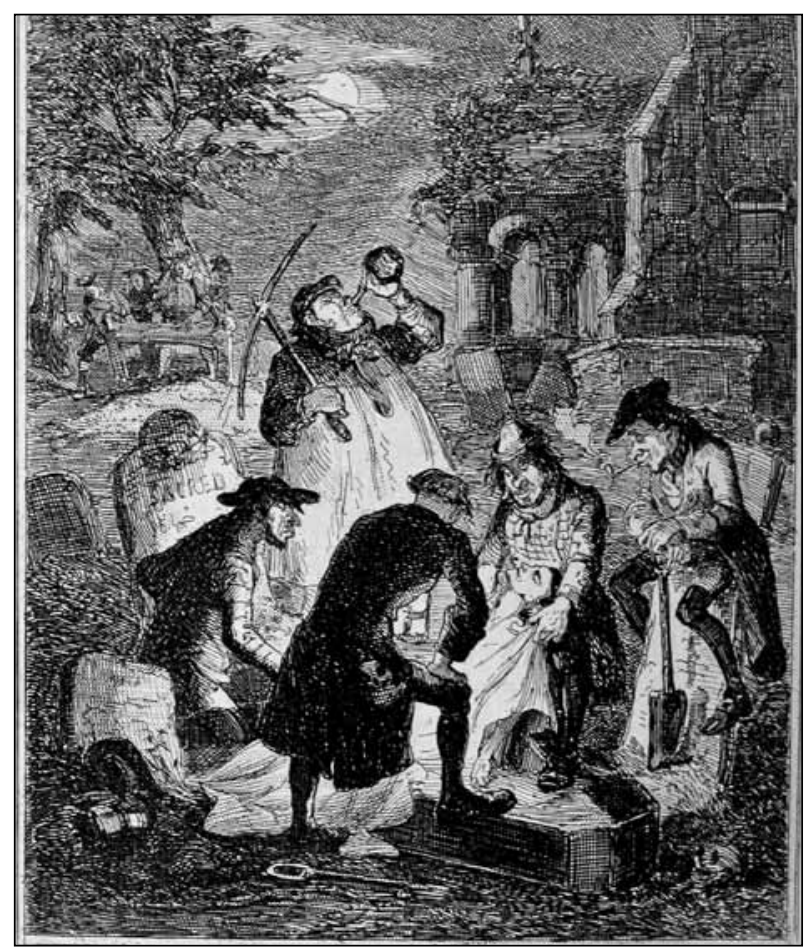

FIGURE I Illustration of resurrectionists at work, accompanying the story of John Holmes and Peter Williams, whipped for stealing dead bodies. Taken from The Chronicles of Crime (London:T Miles and Company; 1887).

\section{Bodysnatching techniques and anti-grave robbing systems}

As the public became more aware of grave robbing practices so it became more difficult to perform them successfully. If it became common knowledge that a specific graveyard had a high incidence of bodysnatching for example, fewer people would buy a burial plot there, and, as a result, more money would be spent heightening security. Several devices and procedures were introduced to protect the bodies: iron gates were fitted with locks and the walls of the graveyard would be built up, sometimes several bricks thick. Many of the snatchers would come back on successive nights in order to loosen bricks, find a secret passageway or to dig a tunnel underneath the wall. Spies, often medical students, were employed to watch over the burial and grave before the actual snatching took place, allowing them to observe how the coffin had been buried in order to formulate an effective plan for retrieving the corpse. ${ }^{3}$

Watch houses were built in the grounds of the churches and many anti-grave robbing devices were fitted to prevent these crimes. Watch houses or towers were erected either at the entrance to the graveyard or in the centre, where someone could maintain a watch over the entire grounds at night. ${ }^{6}$ Watch houses and towers still exist in many parts of Aberdeen and Aberdeenshire - some resembled small stone cottages, like the one still present in St Cyrus while others were tall towers similar to the watch tower in Banchory Ternan (Figure 2). Other such structures can be found in: St Fitticks Kirk, Banchory Devenick, Newhills, Old Dyce Graveyard, Lumphanan, Leochel, Foveran, Collieston Kirk, Peterhead, New Deer, Old St Fergus Kirk and Peterculter. Men would take the 'graveyard shift', keeping watch all night. If a graveyard could not afford a watchtower they simply built the walls higher to stop people from climbing over them.

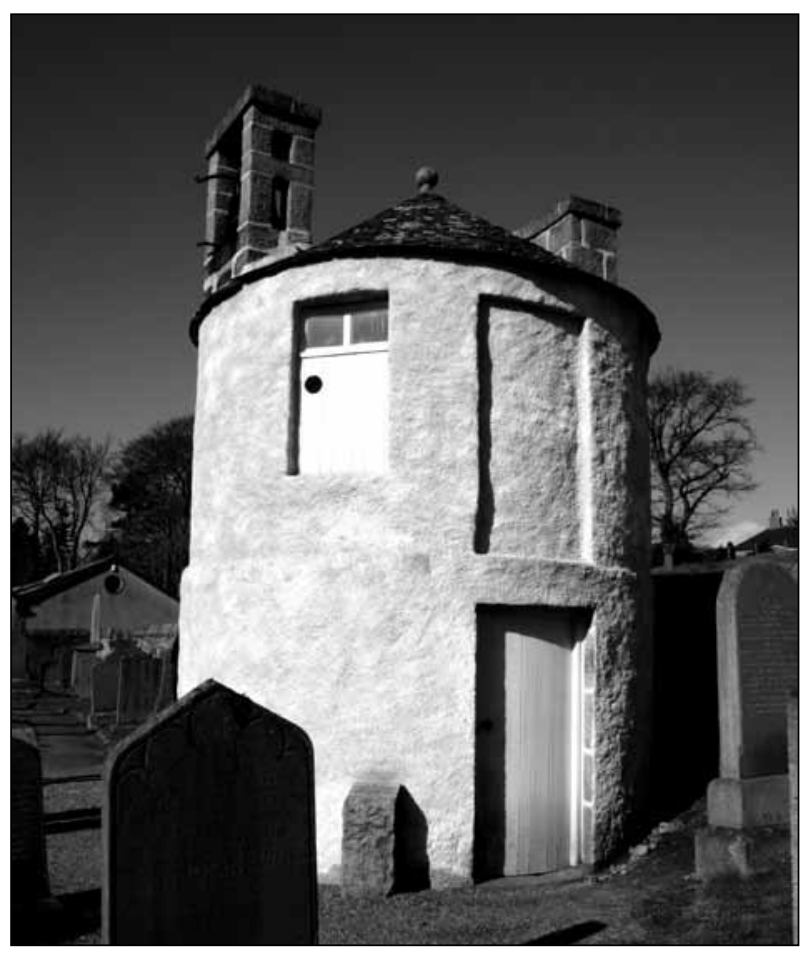

FIGURE 2 Banchory watchtower. Copyright Martyn L Gorman. 
'Mortsafes' were iron cage structures that were placed over newly buried graves for up to a week, after which the bodies were in no condition to be used, became common and were unique to Scotland (Figure 3$).^{7}$ The snatchers soon adapted their techniques to these barriers and began to dig from the sides of the grave, underneath the iron bars. Mort stones (large stone slabs that were placed over a grave) were also used; they had to be lowered down using a 'tackle' which would then be hidden away in a secret location in the graveyard or surrounding area so the grave robbers couldn't use it. ${ }^{7}$ An 'Aberdeenshire mortsafe" was a coffin-shaped stone with a skirt of iron latticework. ${ }^{8}$ In Inverurie these were nicknamed 'irons' and would cost a shilling a day to hire. In 1816, Superintendent Gibb of Aberdeen Harbour Works gifted a mort stone, costing half a crown, to St Fitticks. ${ }^{5}$ Some mort stones and safes still remain in Aberdeenshire and the mortsafe tackle that was used in Inverurie exists to this day.

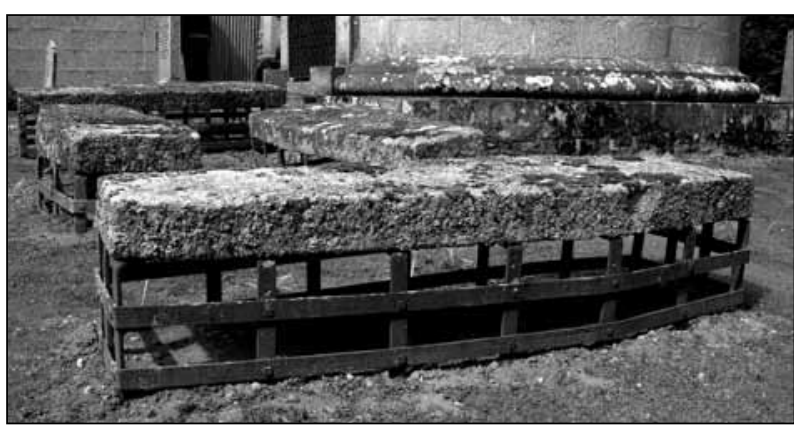

FIGURE 3 Mortsafes in the Cluny Kirkyard. Image courtesy of www.undiscoveredscotland.co.uk

Coffins could be made entirely out of iron as another deterrent, but these were expensive. A cheaper option was to use an iron case that could be removed a week after burial and recycled. In even more affluent areas people would build entire tombs around a grave to further deter snatchers. 'Booby traps' were also used; a spring gun was common - a gun fired when a wire was tripped. ${ }^{7}$

If there was no anti-grave robbing device, the snatcher would dig six feet down to the coffin. Each grave robber had equipment including a lantern, shovel, a sheet (to collect the disturbed soil so as to leave no visible evidence) ${ }^{7}$ and a hook (to prise open the coffins which were often nailed shut), and sometimes a firearm would be taken in case they were disturbed. ${ }^{4}$

Snatchers had to close up the coffin and re-bury it six feet down, and then carry a dead weight of up to $200 \mathrm{lbs}$, depending on the person. Once this was complete the body was smuggled out and taken secretly to an anatomical theatre.

\section{BODYSNATCHING IN ABERDEEN}

Evidence of bodysnatching in Aberdeen is available from several sources, in particular in minutes of meetings of the Aberdeen Medico-Chirurgical Society. The society was formed on 14 December 1789, by a group of medical students led by James McGrigor and James Robertson. ${ }^{2}$ They were unhappy with the limited opportunity for regular dissection and resulting lack in medical education and decided to form the Aberdeen Medical Society, now known as the Aberdeen MedicoChirurgical Society. The minutes from the first meeting, that took place four months after the society formed, state 'That week a plan for anatomical dissection was put in to execution. A dog was dissected'. ' Attention turned to the need for human dissection experience. In April 1794, a letter advocating bodysnatching was sent to the society from former members in London. The Society went on to apparently encourage bodysnatching as a means of providing bodies. The minutes from meetings held from 1806-1808 described how medical students took turns watching the town's churchyards and were expelled from the Society when they failed to do so. ${ }^{3}$ Spital and St Machar churchyards were the most popular graveyards; an amateur bodysnatcher in Aberdeen could earn around ten shillings and six pence for this duty. ${ }^{3}$

Minutes from a meeting on 12 November 1805 read:

Messrs. Officer, Davidson, J Gordon and Rankine intimated to the members that they had procured a subject from the old town churchyard which was safely lodged in the anatomical theatre. Dr Skene was to take the trouble of undertaking the dissection. It is hoped that the exertions of the above will prove a stimulus to the rest of the members. ${ }^{10}$

Dr Charles Skene was a lecturer in anatomy at the University in 1802 and a son of Professor George Skene, a professor of natural history in Aberdeen. He became a Professor of Medicine at Marischal College in 1823. In 1807, Professor Charles Skene 'arranged to give instruction to the members but asks them to see if they can get a subject. ${ }^{3}$ Students were expected to procure, for dissection, a dead body, which he would then examine and use for teaching purposes.

There are many stories about the medical students and professionals in Aberdeen and their involvement in the practice of bodysnatching. One such story describes a night where medical students in Aberdeen travelled by boat to Peterculter to bodysnatch, although this was said to be more of a dare than for any other reason. Another tells of a university professor who entered the gates of the College with a woman, who was in fact a female corpse, disguised in order to be smuggled in for dissection purposes. ${ }^{3}$ 
In her book Aberdeen Doctors at Home and Abroad: The Narrative of a Medical School, Ella Hill Burton Rodger records anecdotes and stories relating to the Aberdeen Medical School. ${ }^{3}$ Rodger's father was a student at the University of Aberdeen, around the time of Charles Skene in 1807, and provided his daughter with his own experiences and the accounts of others from their time at medical school in Aberdeen. ${ }^{3}$ Burton and his peers would gather at night to watch over the graveyards and help their teachers steal bodies. A medical student would receive 10 shillings and 6 pence to watch over a graveyard like St Machar Cathedral or the Spital in old Aberdeen. They were told that they could have one shilling 'to warm the insides of their jacket', meaning that they would receive the rest on completion of their task. ${ }^{3}$ Another particularly gruesome story recounted in the book tells of a child who had drowned in Aberdeen; it soon became common knowledge that a medical student who had obtained the child's body, had dissected it to make a skeleton. He was however discovered by his landlord's wife because of the smell of the cadaver as he 'boiled it in the broth pot.' Another botched attempt to obtain a body led to public rioting when people discovered the thieves. After a boy died a group of students set out to obtain the body, 'in order that it might be found out what was the matter with him'. As they reached the Bridge of Dee they were disturbed and tried to store the body in an ice pocket in the river. However, they were so startled that they let go of the body and it fell into the river. The boy's relatives later managed to recover the body. 'Long Ned', the ringleader of the group, was charged with the offence of bodysnatching, leading to the riot. ${ }^{3}$

\section{ANDREW MOIR - ABERDEEN'S MOST FAMOUS ANATOMIST}

One of Aberdeen's most famous anatomists, Andrew Moir (1806-1844), was recognised by the Royal Colleges of Surgeons in Edinburgh and London for his anatomy courses.

Moir (Figure 4) was educated in Aberdeen at the local grammar school and later at King's College." $\mathrm{He}$ originally studied divinity and was awarded an MA in 1826. ${ }^{2} \mathrm{He}$ had an interest in anatomy, gaining the MRCS diploma of the Royal College of Surgeons of England in 1828. He then became a country practitioner. ${ }^{12} \mathrm{He}$ travelled and attended lectures in Paris by such wellknown surgeons and anatomists as Lisfranc and Duputryen. ${ }^{3}$ The morgue in Paris had a large supply of unclaimed bodies, which intrigued him, and he would visit every day. He returned to Aberdeen in 1828 and became an extramural lecturer in anatomy. He had a command of Latin, Greek, French and German, which allowed him to access sources of information that most of his colleagues could not. His students' anatomical knowledge impressed examiners from Edinburgh and

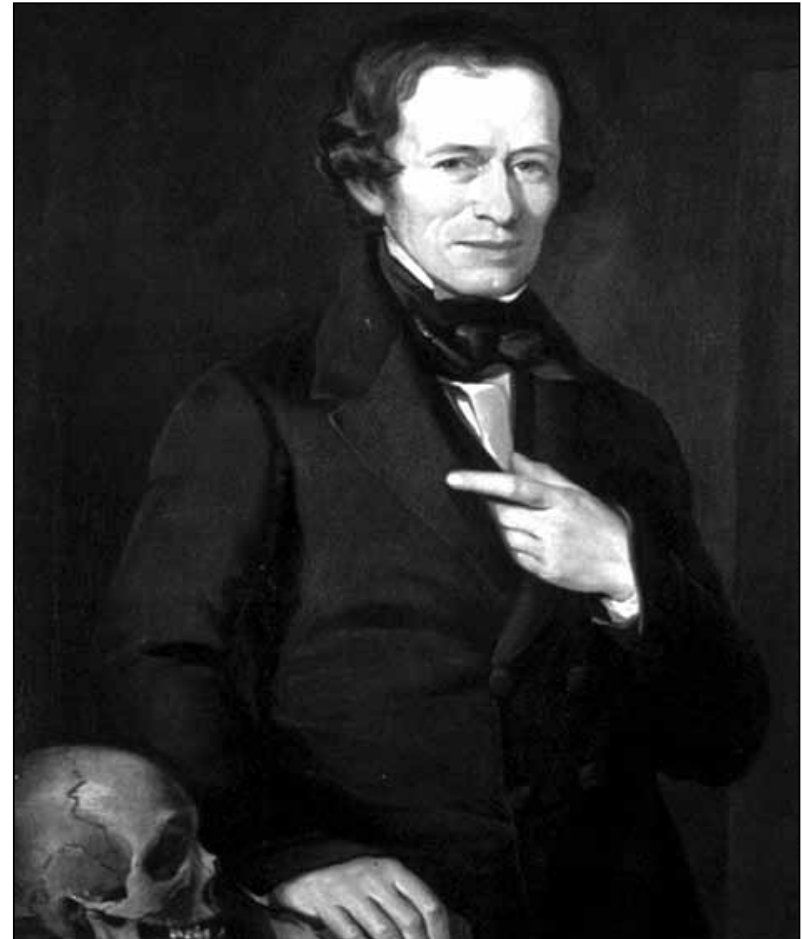

FIGURE 4 One of Aberdeen's most famous anatomists, Andrew Moir (1806-1844). Image courtesy of the University of Aberdeen.

London, such as Sir Astley Cooper. In I83I Moir set up his own anatomical theatre, located on Hospital Row, next to where Woolmanhill Hospital now stands. Soon after it was built however, controversy developed when two young boys, while walking a dog in the area, uncovered some bones that had been buried next to the theatre. The alarm was raised and the theatre was broken into, and two bodies were found. Twenty thousand people, around half the population of Aberdeen at the time, gathered and the bodies were paraded around the streets. Cries of 'burn the Burkin' hoose' [after Burke] could be heard and soon the anatomical theatre was ransacked and burned to the ground. Moir escaped and hid under a gravestone in St Nicholas Kirkyard. ${ }^{14}$ The men of the 79th regiment based at Castlehill Barracks were deployed along with town sergeants and the day patrol in order to restore order. ${ }^{15}$ Moir fled Aberdeen. The following year the Anatomy Act of 1832 was passed allowing for unclaimed bodies to be dissected and used in anatomy theatres. Any person intending to practice anatomy at that time needed to obtain a license from the Home Secretary, and was regularly monitored by one of four anatomy inspectors. Due to his superior anatomy teaching Moir regained the confidence of some of the medical students in Aberdeen. In November 1832 he gave his first introductory lecture. By this time he was a lecturer in anatomy and physiology, but not with the University of Aberdeen.An account of his Aberdeen lecture appeared in the Aberdeen Medical Magazine. ${ }^{16}$ 
He said that: 'Anatomy... is the science of all living bodies whether animal or vegetable' ... 'an inseparable connection, which we shall always find to exist between the anatomy and physiology; to show that the one can never be successfully persecuted without a constant reference to the other and that they were therefore properly speaking on science.' ${ }^{16}$

He went on to mention several anatomists and physiologists whom he believed had contributed greatly to medicine:William Harvey, Bacon, Albrecht von Haller, John Hunter, Friedrich Tiedemann and Sir Charles Bell, saying that his students must 'excel our predecessors.' Moir also highlighted some of the qualities he felt were vital to being a doctor:'I hope that your progress will be sure, and that your minds will become habituated to observation and reflection - qualities so essentially necessary for such of you as mean to attach yourself to the medical profession.' ${ }^{\prime 6}$

When the joint collegiate medical schools ended in Aberdeen, Moir was appointed to the King's College school in 1839 and was awarded a doctorate in medicine.

Moir seemed disheartened by the views of other doctors and wanted them to have a desire to better themselves professionally. He had the opportunities to follow other more lucrative career paths, but instead committed himself to anatomy. He believed that much was left to be learned about the human body when he wrote: 'Anatomy has yet much progress to make, and many anatomical discoveries, which at present seem barren, may in time be brought forward with force in the explanation of phenomena with which they seem at present to have no connection. ${ }^{16}$

\section{REFERENCES}

I Rosner L. The anatomy murders: being the true and spectacular history of Edinburgh's notorious Burke and Hare, and of the man of science who abetted them in the commission of their most heinous crimes. Pennsylvania: University of Pennsylvania Press; 2009.

2 Records of Marischal College New Spalding Club.Vol II: I898; 28. Vol I: |898;231.

3 Rodger E. Aberdeen doctors at home and abroad - the narrative of a medical school. Edinburgh:William Blackwood and Sons; 1893.

4 Adams N. Scottish bodysnatchers. Edinburgh: Goblinshead; 2002.

5 Gorman M. Populace versus bodysnatchers. An introduction to graverobbing in Scotland [Internet]. Aberdeen: University of Aberdeen; 2010 [cited 2011 Nov 28]. Available from: http://www. abdn.ac.uk/bodysnatchers/background.php

6 Ritchie J. Relics of the bodysnatchers. Proc Soc Antiq Scot 1920-21; 55:22I-9.

7 Holder G. Scottish bodysnatchers: a gazetteer. Gloucestershire: The History Press Ltd; 2010.

8 Bodysnatchers at Aberdeen. Press and Journal.1833 Jan 21.

9 Minutes of the Aberdeen Medical Society 1790. Records of the Aberdeen Medico-Chirurgical Society. Aberdeen: University of Aberdeen; 1790.
Before he began teaching in Aberdeen, anatomy was only taught for three hours a week over a five-month period. ${ }^{17} \mathrm{He}$ recognised that this was insufficient, and restructured the lectures, allowing for ten hours to be taught over a six-month period. ${ }^{3}$

Moir died of typhoid on 6 February 1844, aged 38. ${ }^{12}$ The Aberdeen Medical Society was involved in the organisation of his funeral and in ensuring the wellbeing of his family. Hundreds of medical professionals and students attended, indicating the high regard with which he was held in the local medical community. The minute book recorded that there was 'regard for him as a member of the medical profession and as a man'. ${ }^{18}$

\section{CONCLUSION}

The age of bodysnatching saw some gruesome, immoral and illegal acts, some perpetrated by medical students and their teachers. Yet the bodies obtained in this way allowed them to expand their knowledge of the human body, improve their surgical skills and make many anatomical discoveries, providing invaluable information on underlying disease processes. Andrew Moir, arguably Aberdeen's most celebrated anatomist and a figure known throughout Britain, was disliked for his involvement with bodysnatching before the Anatomy Act was passed. However, he was passionate about anatomy and teaching and ensured that anatomy became an integral part of medical teaching in Aberdeen. The Anatomy Act of 1832 effectively ended the era of bodysnatching

10 Minutes of the Aberdeen Medical Society 1806-1808. Records of the Aberdeen Medico-Chirurgical Society. Aberdeen: University of Aberdeen; 1806-8.

II WDM. He hid in the churchyard. Evening Express. 1853 Jan 31.

12 Bayliss RA. Andrew Moir: an Aberdeen anatomist. Scottish Medical Journal 1980; 25:315-9.

I3 Mitchell GAG. Anatomical and resurrectionist activities in northern Scotland. Journal of the History of Medicine and Allied Sciences 1949: 4I7-30.

14 Demolition of the Anatomical Theatre. Aberdeen Observer. I83। Dec 23.

15 Irvine $\mathrm{H}$. The diced cap - the story of Aberdeen city police. Aberdeen: Aberdeen University Press; 1972.

$16 \mathrm{Mr}$ Moirs 3rd introductory lecture. Aberdeen Medical Magazine. 1835 April.

17 The late Dr Andrew Moir. Aberdeen Journal 1844.

18 Minutes of Aberdeen Medical Society. Records of the Aberdeen Medico-Chirurgical Society. Aberdeen: University of Aberdeen; 1844. 